\title{
Alchemical Journey into the Divine in Victorian Fairy Tales
}

\author{
Emilia Wieliczko-Paprota (iDhttps://orcid.org/0000-0001-8662-6490 \\ Institute of Polish Language and Literature \\ University of Gdańsk \\ emiliawieliczko@wp.pl
}

\begin{abstract}
This article demonstrates the importance of alchemical symbolism in Victorian fairy tales. Contrary to Jungian analysts who conceived alchemy as forgotten knowledge, this study shows the vivid tradition of alchemical symbolism in Victorian literature. This work takes the readers through the first stage of the alchemical opus reflected in fairy tale symbols, explains the psychological and spiritual purposes of alchemy and helps them to understand the Victorian visions of mystical transformation. It emphasises the importance of spirituality in Victorian times and accounts for the similarity between Victorian and alchemical paths of transformation of the self.
\end{abstract}

Keywords: fairy tales, mysticism, alchemy, subconsciousness, psyche

Słowa kluczowe: bajki, mistyka, alchemia, podświadomość, psyche

\section{Victorian interest in alchemical science}

Nineteenth-century fantasy fiction derived its form from a different type of inspiration than modern fantasy fiction. As Michel Foucault accurately noted, regarding Flaubert's imagination, nineteenth-century fantasy was more erudite than imaginative: "This domain of phantasms is no longer the night, the sleep of reason, or the uncertain void that stands before desire, but, on the contrary, wakefulness, untiring attention, zealous erudition, and constant vigilance." Although, as we will see, Victorian fairy tales originate in the subconsciousness, the inspiration for symbolic

${ }^{1}$ M. Foucault, Fantasia of the Library, [in:] Language, Counter-Memory, Practice: Selected Essays and Interviews, D.F. Bouchard (ed.), New York 1977, p. 90. 
embodiments comes from the world "between the book and the lamp." ance of alchemical symbolism in Victorian fairy tales is a consequence of a revival of occult science in Victorian England. I would argue with Marie-Louise von Franz, who declared that Carl Gustav Jung was the person who "practically dug [alchemical knowledge] up from the dunghill of the past, for it was a forgotten and despised field of investigation which he has suddenly revived."3 Jung's idea of treating alchemy as a process of psychological individuation was taken from nineteenth-century occultists, who considered alchemy the key to spiritual illumination. L.R. Principe and W.R. Newman, ${ }^{4}$ in their short history of alchemy, emphasised that nineteenth-century occultism brought a massive change in the perception of the alchemical opus. It was no longer exclusively a field of scientific experiment but was seen as a profoundly mystical system. Alchemy fitted the Victorian frame of mind, which was based on scientific naturalism and empirical perception; it combined the desire for a spiritual antidote to decadent soul-sickness with science. The main value of alchemy was seen in a connection with the physical world, "in the application of a mystical doctrine to physical things." Hence, alchemy was distinguished from other forms of spiritual mysticism, which required faith derived from sensual experience. In "physical mysticism" the divine was formed into matter, and matter spiritualised into the divine. The force which mediates between matter and spirit connects us directly with the core of this article, since it is imagination, as Edward Waite argued, which "endows the will with power over a universal agent."

\section{Imagination in alchemy and Victorian fairy tale writing}

Before we delve into the depth of the alchemical and Victorian understanding of the function of imagination, we have to propose a new approach to the Victorian fairy tale as a genre. The problem with Victorian fairy tales is that there are no strict determinants which differentiate the fairy tale from other works of imagination. Confusion arises because the Victorians attached the term "fairy tale" to all fantasy works, whether didactic, legendary or romance. It is sufficient to look at the anthologies of Victorian fairy tales edited by Jack Zipes, Michael Patrick Hearn, or Jonathan $\mathrm{Cott}^{7}$ to understand how different types of literary works may be collected together under one category. Before the Victorians delineated the fairy tale genre, it had

${ }^{2}$ Ibidem, p. 90.

${ }^{3}$ M.-L. von Franz, Alchemy: An Introduction to the Symbolism and the Psychology, Toronto 1980, p. 13.

${ }^{4}$ L.R. Principe, W.R. Newman, Alchemy Tried in Fire: Starkey, Boyle, and the Fate of Helmontian Chymistry, Chicago-London 2002, p. 35.

${ }^{5}$ M.A. Atwood, Hermetic Philosophy and Alchemy. A Suggestive Inquiry into 'The Hermetic Mystery'[1918], New York 2010, p. 59.

${ }^{6}$ A.E. Waite, Azoth, Or, The Star in the East, London 1893, p. 110.

${ }^{7}$ J. Zipes, Victorian Fairy Tales: The Revolt of the Fairies and Elves, New York 1987; M.P. Hearn, The Victorian Fairy Tale Book, New York 1988; J. Cott, Beyond the Looking Glass: Extraordinary Works of Fantasy and Fairy Tales, Stonehill 1973. 
undergone various transformations of purpose. The aim of fairy tales in the early and mid-Victorian era was determined by social and moral demands. The conventional fairy tale, as J. Zipes named this type of children's literature, ${ }^{8}$ was aimed at reconnecting the reader with the principles of Victorian society. Elves, dwarfs, goblins and entire magic worlds served clear didactic purposes. At the end of the nineteenth century, fantasy fiction became more imaginative and symbolic. It stemmed from a dissatisfaction with reality, from a deep-rooted need for something more profound and unchangeable in the changing world of an industrial empire. Late nineteenth-century fairy tales started to reflect the collective unconscious and archetypal patterns of mind. They became the work of primary imagination in contrast to different products of fantasy which were influenced by mere fancy. The division between imagination and fancy is important in Victorian culture. Following Coleridge and the German Romantics, Victorians believed that "primary imagination" is a divine power. As W.H. Auden explained: "The concern of the Primary Imagination, its only concern, is with sacred beings and sacred events. The sacred is that to which it is obliged to respond; the profane is that to which it cannot respond." "Fancy," on the other hand, is a scissors-and-paste job of the mind. Primary imagination created late Victorian fairy tales and constituted the basis of the genre itself, relating literature to the alchemical imagination. Imagination in alchemy plays a prominent role, as it constitutes both the divine force rising to the light of consciousness and the unconscious sacred first principle hidden in the dungeons of the psyche. In the Emerald Tablet this divine force constructs the World and rules the self. "Its father is the Sun, its Mother is the Moon. The Wind carried it in its womb, the Earth breastfed it." 10 The Father-Sun is the force which seeks form in order to express its own power. The Mother is a receptive organ, human unconsciousness, which receives the force and releases it into the light of consciousness. The Wind is the imagination which implants the divine seed into form (Earth/Matter/Symbol). This process is best pictured in Robert Fludd's The Art of Memory. In one of the images the oculus imaginationis is placed in the centre of the forehead, where the observed events are transformed into images and projected onto a screen behind a man. The eye of imagination is focused on the invisible side of human nature but the projection is embodied in a reality abundant with forms ready to be turned into symbols. That is how, through imagination, the unintelligible, divine Logos becomes comprehensible. Jacob Boehme argues that the impulse of God's Mind dwells in the depths of our soul ready to be incorporated into reality by the active force of imagination. ${ }^{11}$

The imaginative character of the alchemical opus was very often highlighted by alchemists: "The substance of the vessel exhibits a great variety of forms; it will become liquid, and again coagulate a hundred times a day; sometimes it will present

\footnotetext{
${ }^{8}$ J. Zipes, op. cit., p. XXII.

${ }^{9}$ W.H. Auden, Phantasy and Reality in Poetry, [in:] In Solitude, for Company: W.H Auden After 1940, K. Bucknell, N. Jenkins (eds.), Oxford 1995, p. 187.

${ }^{10}$ Emerald Tablet, http://www.alchemywebsite.com/emerald.html [access: 27.07.2017].

${ }^{11}$ K. Fisher, Converse in the Spirit: William Blake, Jacob Boehme, and the Creative Spirit, Cranbury 2004, p. 46.
} 
the appearance of fishes' eyes, and then again of tiny silver trees." ${ }^{12}$ If we compare some alchemical engravings with fairy tale visions, we may understand how they mirror the same desire to activate the unknown with the power of imagination. For George MacDonald, one of the most ingenious Victorian fairy tale writers, imagination reaches the deepest layers of unconsciousness. It is independent of the artist, who is a mere receptor of underground life where a hidden God blows out the "candle of our consciousness." ${ }^{13}$ Imagination, an unknown and unintelligible source, writes luminous words upon the wall of the artist's mind. They may blossom into the light of sudden mystical comprehension or create a beast of terrifying darkness. The writer may hope for endless beauty, but he or she should fear the "apparition of such monsters as would be generated in the sickness of a decay." ${ }^{14}$ Similarly, in Rosarium Philosophorum imagination may lead to "things that we know not of nature cometh forth, although we know it sufficeth us, but cannot give any reason for it, because they are dark and profound and perhaps hidden underneath the earth." ${ }^{15}$ In MacDonald's fairy tales there are ambiguous forms of shadows and beasts which "we know not of nature." We may say that they spring up from "primal chaos," from an alchemical darkness in which "all things asleep. Rude, unformed, without shape, form or any good, Out of which God created all things as it stood." ${ }^{\prime \prime}$ Hence, fantasy was seen in Victorian times as light thrown into the chaos of undefined forms, bringing the numinous feeling of the sacred. MacDonald's creative man, the writer and artist, "is rather thought than thinking"; he "may well himself discover truth in what he wrote," for "the true soul sees, or will come to see, that his words, his figures always represent more than they are able to present," ${ }^{17}$ as they do not depend on the human mind. Fairy tales were like vessels for alchemists in which materials are transformed, and at the same time they bring transformation to the one who acts.

Fairy tales created by the active imagination are transcriptions or invitations to a spiritual journey into the depth of the self. The alchemical opus is very often described as a journey: "it is natural for man to lead a life as a pilgrim"18 - says Michael Meier in his allegory about the journey to Hermes' grave. In fairy tales, the heroes "make a link between heaven and earth, give actual and familiar significance to the most awful mysteries of faith"19 in the journey to a wonderland which reflects the inward peregrination. As the protagonist goes further into the depths of an unknown

${ }^{12}$ Eirenaeus Philalethes, An Open Entrance to the Closed Palace of the King, London 1667, http:// www.alchemywebsite.com/openentr.html [access: 27.07.2017].

${ }^{13}$ G. MacDonald, A Dish of Orts [1867], https://www.gutenberg.org/files/9393/9393-h/9393-h.htm [access: 27.07.2017].

${ }^{14}$ Ibidem.

${ }_{15}$ The Rosary of the Philosophers [1550], http://www.alchemywebsite.com/rosary2.html [access: 27.07.2017].

16 S. Forman, Of the Division of Chaos [1595], http://www.levity.com/alchemy/forman_chaos.html [access: 27.07.2017].

${ }^{17}$ G. MacDonald, op. cit.

${ }^{18}$ M. Maier, A Subtle Allegory [1617], http://www.alchemywebsite.com/maier.html [access: 28.07.2017].

19 E. Underhill, The Miracles of Our Lady Saint Mary [1905], New York 2015, p. 4. 
land, so the reader is transported to deeper layers of inner landscapes. This consubstantial world of fairies gives the opportunity to perceive reality in the truest view; it is the territory where everything seems to possess an original meaning. The world in-between, either fairy or alchemical, awakens the divine, suggests the impossible, prepares one to embrace the sacred. That is what Victorians expected from the works of fantastic imagination, of nonsense and wonder: "The sudden clash of a happy surprise seems to give the buoyant vibratory movement to the as yet semi-fluid, spongy soil of the phantasy, which sends up the peculiar rising mist, seen through which the grotesque proportions and relations are peculiarly exaggerated and take on new significances. ${ }^{20}$ We may say that fairy tales are like rituals of initiation into the divine. Thomas Carlyle believed that: "Fantasy being the organ of the Godlike [...]. Man thereby, though based, to all seeming, on the small Visible, does nevertheless extend down into the infinite deeps of the Invisible, of which Invisible, indeed, his Life is properly the bodying forth." ${ }^{21}$ It is not in logic and reason where the "plant for Eternity" may blossom but in "fantasy and heart." 22

\section{Into the darkness - the alchemical and Victorian journey into the unconsciousness}

The active imagination in Victorian fairy tales brings forth the unknown and hidden divine reality which dwells underneath the limited consciousness. But the journey to the sacred leads through the dark realms of the unknown. During the nineteenth century the perspective on man changed. The conscious ego was no longer perceived to be the only agent responsible for forming thoughts and ideas. Deep, dark forces were located in the human mind. William James, an American psychologist who was famous in Victorian England, noticed that the nineteenth-century mind became "Fantastic, ignoble, hardly human, or frankly non-human." 23 These ambiguous forms dwelling on the margins of the conscious mind became a Victorian fascination and fear. With scientific obsession, Victorian psychologists observed and deconstructed multiple personalities, considering madness a visible sign of the obscure unconscious power which could overflow and manipulate man. The nineteenth-century psyche became divided into a clearly defined and limited "A-region" of the conscious ego and an enigmatic, vast "B-region" of the unconscious self. True identity became rooted in the abyss of an amorphous sea. Our inactive memories, "passions, impulses, likes, dislikes, and prejudices, our intuitions, hypotheses, fancies, superstitions, persuasions, convictions and in general all our non-rational operations come from it." ${ }^{24}$ The

${ }^{20}$ H.A. Page, Children and Children's Books, "The Contemporary Review" 1869, vol. XI, MayAugust, p. 11.

${ }_{21}$ T. Carlyle, Sartor Resartus: The Life and Opinions of Herr Teufelsdrockh: In Three Books, London 1889, p. 211.

${ }_{22}^{2}$ Ibidem, p. 218.

${ }^{23}$ W. James, Essays in Psychical Research, Harvard 1986, p. 194.

${ }^{24}$ Idem, The Varieties of Religious Experience. A Study in Human Nature, London 1917, p. 484. 
depths of the subliminal self consist not only of suppressed memories and feelings but also contain the history of the universe and the paths of evolution. The animal heritage inhabiting the unconsciousness was the worst fear of Victorian researchers of the psyche. Instincts and atavistic behaviours were believed to lie in the psyche of the ordinary man, waiting for a suitable moment to lean over the darkness. The depth of unconsciousness hides the Divine in the indescribable world of fears. We may hope, said Samuel Butler, "to familiarize ourselves with the world of forms that teem within the bosom of these seas by observing the few that now and again come to the surface and soon return into the deep, ${ }^{25}$ but it is hopeless to cross the bridge to an unknown world with the power of consciousness and the language of reason. That is the reason why fantasy and imagination became the Victorian language of the sacred.

The fear and fascination accompanying the latest developments in psychology was yet another explanation of the Victorian interest in alchemy. The alchemist had to dive into the chaos of unconsciousness to raise the unknown and dark matter to the level of awareness. In the act of Nigredo, the previously unknown layers of psyche are mingled, conjugated with the Ego and then coalesced into perfect unity. However, at the beginning, the boundaries of the Ego, which previously maintained a safe and unchangeable personality, are dissolved in philosophical putrefaction, which is "nothing else but a corruption and destruction." ${ }^{26}$ Once the flood of darkness overpowers the consciousness a dangerous journey begins. The adept has to regress into undigested matter, into the kingdom of disorder which "could not be the work of a God, formless as it was" ${ }^{\prime 27}$ and let the psyche die in the arms of forces stronger than the will as "every seed is useless if it remains as it is, if it does not decay and become black." ${ }^{28}$ In the first emblem of Splendor Solis, the two philosophers observe the stream of unconsciousness digesting the Sun of consciousness in the black waters. The distorted face of the sun captured in the curved waters is the symbol of the horror of Nigredo and danger of the descent into the underground realms. This dreadful state is often pictured in Victorian fairy tales.

At the beginning of Nigredo, the conjunction of opposites begets the battle between two unbalanced principles. The unconscious matter dissolves the strict boundaries of Ego, which previously assumed itself as an exclusive governor of the psyche, whereas now, after the conjunction, it has to realize its subordination. This causes conflict and chaos. The Ego has to descend to the centre of its own source, accept and open itself to the dark side. The conjunction of unbalanced elements is very often the leading theme of Victorian fairy tales. In Mary de Morgan's Seeds of Love, ${ }^{29}$ after the conjunction between the king's son and Blanchelys, the girl's jealous sister Zaire decides to destroy the marriage. The marriage between a king and a queen is

${ }_{25}$ S. Butler, Unconscious Memory [1880], http://www.gutenberg.org/files/6605/6605-h/6605-h.htm [access 28.07.2017].

${ }^{26}$ The Rosary of the Philosophers, op. cit.

${ }^{27}$ M.-A. Crasselame, The Light Coming Out of the Darkness, http://www.alchemywebsite.com/crassel.html [access: 29.07.2017].

${ }^{28}$ Ibidem.

${ }^{29}$ M. de Morgan, Seeds of Love, [in:] eadem, On a Pincushion, and Other Fairy Tales, London 1877. 
a typical symbol of conjunctio and the sudden separation after the ceremony begets the Nigredo. In the Madathanus parabola, the beautiful bride and groom "instead of a bridal bed and brilliant wedding $[. .$.$] they were condemned to a strong and everlast-$ ing prison," ${ }^{30}$ where they were dissolved in heat and tears. The symbolic marriage at the beginning of the opus is destroyed in order to transform the dual relationship into a mystical union. In Seeds of Love the demon of envy and the black haired sister tear down the love between the royal couple. They bury the snake under the ground of the rose bush - the symbol of love:

Zaire waited till night, and then she took a spade and went into the garden to dig at the roots of the rose-tree [...]. She dug and dug till she came to the long deep roots that went far into the earth [...]. Then she took the snake in her little white hand and placed it among the tree's roots. ${ }^{31}$

This act is full of alchemical meaning. The rose in alchemy is a symbol of a mystical marriage of opposites. It represents the reconstruction of the separate elements and restoration on the level of union around the mystical centre. The Mystical Rose is very often assisted by Death, which disperses elements in order to attach them to the one centre in perfect harmony. That is why the snake often coils around the roots of the rose. In emblem fifty of Atalanta Fugiens, a woman is buried in a tomb with the serpent-dragon coiled around her. We read: "The Mansion of Dragons is in Caverns of the Earth; but of Men upon the Earth, in the Immediate Air; which two Elements are contrary and yet are appointed by the Philosopher to be joined together, that one may act upon the Other." 32 The two principles of below and above have to be united. The snake-dragon has to stifle and dissolve the woman's body: "and the more he winds and coils itself about her, the more his body, mixed with the limbs of the woman, inclines towards death, and he turns entirely into blood." 33 The death of the rose in Seeds of Love brings depression, desolation and horror to Queen Blanchelys. She enters the dark night of the soul.

Nigredo is a death-like experience, often represented by regression to childhood or the place of birth where the strong, mature Ego breaks down and primitive feelings or infantile fears rush to the surface of the psyche. Blanchelys "wandered and wandered till she came to the village where she was born, and to the little house by the bridge where she had lived." ${ }^{4}$ The regression throws her into madness and a death-like state. People "stared at her and thought her mad" 35 and considered her dead. "Queen Blanchelys has now been dead many years." 36 The images of joy and happiness evoke emptiness in her feelings, and the pictures of death, torture and pain bring consolation and lead to a solution. The Nigredo depression is morbidity

${ }^{30}$ The Parabola of Madathanus, http:/www.alchemywebsite.com/parabola.html [access: 28.07.2017].

31 M. de Morgan, op. cit., p. 46.

32 M. Maier, Atalanta fugiens, http://www.alchemywebsite.com/atalanta.html [access: 30.07.2017].

33 Ibidem.

34 M. de Morgan, op. cit., p. 48.

35 Ibidem.

${ }^{36}$ Ibidem, p. 56. 
and restlessness to the body and mind. Blanchelys' wandering is emphasized several times in the short story: "so she went on and on, night and day, till her feet were sore and her face burnt with the sun"; 37 "so she went on and on and on, till she was so weary she could toil no farther." ${ }^{38}$ This unrestful travelling transforms the Nigredo depression into a creative act which brings a solution to the tortured Ego. Blanchelys sacrifices herself and gives her blood to the withered rose, reviving the bond with her husband and dissolving her Ego in the symbol of mystical marriage. The white rose becomes red, which is the tincture of sacrificial blood, and becomes a fully blossomed mystical flower. As C.G. Jung wrote:

In the state of "whiteness" one does not live in the true sense of the word. It is a sort of abstract, ideal state. In order to make it come alive, it must have "blood" [...]. Blood alone can re-animate a glorious state of consciousness in which the last trace of blackness is dissolved, in which the devil no longer has an autonomous existence but rejoins the profound unity of psyche. ${ }^{39}$

Nigredo brings death and grief to the newly formed structure of the psyche. In Mary de Morgan's Seeds of Love depression and madness transform love into a mystical union. We may find a similar motif in Laurence Housman's fairy tale The Moon-Flower. ${ }^{40}$ The Moon Princess Berenice, who descends to Earth to find her lost pearl, and the Prince, who lost himself in a dense forest during the hunt, are trapped in a gnome's house. The love between them leads to a mystical marriage and links the earth with the moon: "So the Prince drew off the ring from her finger, and set it upon his own; and as he did so he felt indeed the heart of the Moon-people become his own, and the love of the Moon strike root in him.." ${ }^{\prime 1}$ After this symbolic act, the royal couple attempt to escape from the prison-house but the Nigredo forces symbolised by the red mole-gnome transform the Princess into a rooted flower, in order to pull her down into the underground kingdom. The abandoned prince and the threatened princess fall deep into depression. He "wandered like a ghost from place to place, filling the empty garden with memories of her presence, and sighing over and over again the music of her name", ${ }^{42}$ she "swayed down, and leaned, and fell weeping against his breast." ${ }^{\prime 43}$ The male and female after the conjunction fall deep into a desolate state of imprisonment. In alchemy the couple is usually put away in a tomb or buried under the ground, but depression brings forth the Light. In The Moon-Flower, the factor of the final transformation comes from beneath the moon-flower's roots: "[O]ut sprang the tiny child like a lobe of quicksilver, laughing merrily with its first leap into the light." ${ }^{44}$ Quicksilver is the alchemical symbol of Mercury - the god of transformation. Mercury is a mysterious god with many faces; being the symbol of death and

${ }^{37}$ Ibidem, p. 48.

${ }^{38}$ Ibidem, p. 49.

${ }^{39}$ C.G. Jung, C.G. Jung Speaking: Interviews and Encounters, W. McGuire, R.F.C. Hull (eds.), Princeton 1987, p. 228.

${ }^{40}$ L. Housman, The Moon-Flower, [in:] idem, A Doorway in Fairyland, New York 1900.

${ }^{41}$ Ibidem, p. 171.

${ }^{42}$ Ibidem, p. 173.

43 Ibidem, p. 175.

${ }^{44}$ Ibidem, p. 177. 
resurrection, he initiates the alchemical opus and is the end result of transcendental transformation. His character reflects this ambivalence: in the first stages of the alchemical process he can be vicious and dangerous, but in the end he is the Treasure and Medicine. This duality is emphasised in The Moon-Flower. The quicksilver child comes out of the same kingdom as the red-mole gnome that imprisoned the couple. It escapes the unconscious realm and ascends to the spiritual kingdom, altering the dark image of the self to that of an enlightened one. In Rosary of Philosophers the "extraction of the soul" is expressed in the same manner as in Laurence Housman's fairy tale. The soul of the hermaphrodite, symbolised by the tiny homunculus, rises into heaven leaving the dead body in the tomb-like bed. The torments suffered during this separation are horrendous, but essential. When the divine homunculus returns, he revives and transforms the dead hermaphrodite: "A dead thing will be revived and a sick thing be healed. It behoveth thee to join the body and the soul together [...]." ${ }^{\prime 4}$ The quicksilver child in The Moon-Flower returns and transforms the Moon Princess back to her original form. The royal couple ascends to the moon in order to live in the silvery palace. In the Rosary the revived hermaphrodite triumphs upon the crescent moon and the queen recites lines which summarise Berenice's journey to the Earth:

[...] before my body was as it were outcast

Neither was I yet a mother, until I was again born

Then I got strength of all herbs and roots

I have obtained victory in all diseases

I was the name of my Son

And being joined with him, I came forth with him... ${ }^{46}$

The transformation of the dark psyche is one of the leading motifs in Laurence Housman's fairy tales. We may find different alchemical embodiments of Mercury in his small masterpieces in which the evil spirit is transformed into the redeemer and solution. In The Gentle Cockatrice ${ }^{47}$ the motif of the dragon is yet another personification of the dangerous Mercury changed into the saviour. The alchemical dragon is as ambivalent as Mercurius himself: "A savage Dragon lives in the forest, / Most venomous he is [...] / In the hour of his death / His venom becomes the great Medicine." 48 The philosophical Dragon embodies all fears and boundaries of the Ego, which descend to the unconscious realm; the Ego cannot be destroyed in battle but has to be transformed or domesticated. In Laurence Housman's fairy tale, Beppo becomes a friend of the dragon, which he brings to life from the coldness of the underground kingdom. Beppo escapes from home to a cave in the mountains where he intends to "make himself a castle and dream dreams." 49 The regression to the centre of the earth does not bring him idyllic peace; the deeper he descends the more aggressive he becomes:

\footnotetext{
${ }^{45}$ The Rosary of the Philosophers, op. cit.

46 Ibidem.

${ }^{47}$ L. Housman, The Gentle Cockatrice, [in:] idem, The Blue Moon, London 1904.

${ }^{48}$ Book of Lambspring [1599], http://www.alchemywebsite.com/lambtext.html [access: 01.08.2017].

${ }^{49}$ L. Housman, The Gentle..., op. cit., p. 156.
} 
[...] he began to rise to great heights in his own imagination. First he had been a poor outlaw, a mere sheep-stealer hiding from men's clutches; then he became a robber-chief; and at last he was no less than the king of the mountains. [...]. Tomorrow he meant to catch a kid and roast it and eat it. Why should he ever go home again? ${ }^{50}$

The aggressive dreams come from the dark side of the self, which, unblocked in the Nigredo, overflow the psyche with previously hidden shadows and animal instincts. Animals very often describe the emotional state in the dark time of putrefaction: "The wolf and the dog are in this field [...]. They are full of jealousy, fury, rage and madness, one kills the other, and from them comes a great poison." ${ }^{51}$ The unknown, suppressed and forgotten elements of unconscious life rush to the surface of the psyche and cause a state of uncontrolled chaos. When Beppo makes a fire in the cave, all the demons jump out of the unconsciousness. The constant warmth of the fire melts away all the boundaries of the Ego; from the previously fixed stone of the cavern comes out the great cockatrice. The putrefaction is usually achieved by boiling a substance over the fire. In The Donum Dei, a black dragon emerges in a vessel placed over a gentle fire; it is kept imprisoned and boiled until it transforms into a white substance. Beppo warms the cavern and discovers his own cockatrice: "Very slowly indeed the great Cockatrice, which had lain buried for thousands of years, out of reach of light or heat of the sun, was coming round again to life." ${ }^{52}$ At first, Beppo wants to release the Dragon, but when it turns out that its tail lies under the village, he decides to put it to sleep again. Beppo rescues the city from a huge earthquake and overcomes his demons. His transformation allows him to enter a different realm of a peaceful land of green cockatrices: "And Beppo's native town lay safe, because he had learned from Cockatrice to be patient and gentle, and had gone to be king of a green world where everything was harmless. ${ }^{153}$ Out of the philosophical Dragon, the wise and modest alchemist can create the perfect world, a paradise prepared for man by God.

The alchemical dragons have to be overcome for the alchemist to enter the next stage of psychological individuation. Beppo puts the dragon to sleep on a stone in the cavern; Nigel from Edith Nesbit's The Island of the Nine Whirlpools ${ }^{54}$ turns the dragon into stone and makes the griffin devour itself. The two dragons from Nesbit's fairy tale guard the entrance to the Island with the imprisoned Princess. The Princess is not an ordinary royal daughter; she is the divine alchemical homunculus. She is prepared in a witch's cave in a "copper cauldron" and represents the alchemical artificial child. The homunculus is the new embodiment of the conjoined psyche, the ideal form of the emerging self. In Nesbit's fairy tale it reflects perfection and pureness: "Your child will have hair as golden as your crown, eyes as blue as your sapphires. [...]. Its soul will be white and sweet as your lilies, and your diamonds will

${ }^{50}$ Ibidem, p. 157.

${ }^{51}$ Book of Lambspring, op. cit.

${ }^{52}$ L. Housman, The Gentle..., op. cit., p. 160.

53 Ibidem, p. 171.

${ }_{54}$ E. Nesbit, The Island of the Nine Whirpools, [in:] eadem, The Book of Dragons [1901], New York 1986. 
be no clearer than its wits." 55 The production of the alchemical child is the dream of the alchemist to deliver perfection by means of art; he gives birth to divinity and wisdom by the conjunction of the Sun (consciousness) and the Moon (unconsciousness). However, the divine child in alchemy very often has to be sacrificed and killed in a state of Nigredo. In The Book of Lambspring, the divine son, after the initiation into the realm of spiritual knowledge, is swallowed by his father in excessive joy at his return from his spiritual journey; the perfect youth in the tenth image of Splendor Solis is decapitated and dismembered by the black king in order to be resurrected as a fully mature divine form. The death of the new born alchemist after the conjunction of opposites is inevitable. In our fairy tale, the princess is sent to a death-like prison by her own father with whom she had argued. The divine homunculus prepared by the witch unites itself strongly with the fragile mother's world but rejects the black and dangerous father's reality. To achieve the balance between the two principles, she has to be sentenced to death. The father symbol in Nesbit's fairy tale is significant, it possesses all the Nigredo attributes: he looked "as black as thunder, with his black raven hopping after him" ${ }^{56}$ (a raven in alchemy is a symbol of Nigredo and a reflection of the shadow), "boiling different coloured things in crucibles and copying charms in curious twisted letters from old brown books with mold stains on their yellowy pages." ${ }^{\prime 7}$ The princess is sentenced to prison on the island of suspension, where time does not pass and the gate is secured by both a dragon and a griffin. To rescue her, Nigel has to pass nine whirlpools, kill the dragon and make the griffin devour itself. The last symbol is very significant in alchemy. The griffin:

[...] had been artificially made by the King-enchanter, and the two halves had never really got used to each other. So now the eagle half of the griffin, [...], believed that it was fighting a lion, [...], thought it was fighting an eagle [...]. So the griffin rolled over and over, one end of it fighting with the other, till the eagle end pecked the lion end to death, and the lion end tore the eagle end with its claws till it died. And so the griffin that was made of a lion and an eagle perished $[\ldots] .^{58}$

The griffin which devours itself refers to the Ouroboros symbol. Jung explained it in Mysterium Conjunctionis: "[...] the idea that the dragon or Sol must die is an essential part of the mystery of transformation. [...] It signifies the overcoming of the old and obsolete as well as the dangerous preliminary stages which are characterized by animal-symbolism." 59 The two elements of the unbalanced psyche are finally united in the symbol of the animal devouring itself. The princess who previously rejected the male principle in her life overcomes the chaos of the first stage of Nigredo and unites herself with the male rescuer.

${ }^{55}$ Ibidem, p. 86.

${ }^{56}$ Ibidem.

${ }^{57}$ Ibidem, p. 87.

${ }^{58}$ Ibidem, p. 98.

${ }_{59}$ C.G. Jung, Mysterium Coniunctionis, [in:] The Collected Works of C.G. Jung, G. Adler (ed.), New York 1963, p. 142. 


\section{Conclusions}

During the Victorian era when the self was newly perceived, and the old perspective on selfhood seen as a transcendental entity with strong individual inclinations and an immortal, unchangeable soul was no longer valid, alchemy played the role of a teacher. Under the new theories of evolution and the subliminal realms, the new Ego was conceived as a multiple structure into which Alchemy showed the path. One of the aims in alchemy is to transform the Ego, which is stifled within the boundaries of its own limitations, into the fully aware self, conjoined with the unconsciousness. This true image of man exposed to the sudden impulses of uncontrolled drives brought a fear of the unknown in the nineteenth century. Alchemy played a significant role in the initiation into the path of unexplored realms. The necessity of temporary madness, the feeling of fear and loss described in alchemical texts helped to prepare Victorians for the inner journey to the absolute transmutation. At the end the Ego formed in the alchemical opus and desired in Victorian times is the ruler of the realms above and beyond.

Victorians not only refreshed the knowledge on this ancient science but they also conveyed it in their Art. Imagination, which in Alchemy is the means to the Divine in the nineteenth century, helped to establish Art as a sacred activity. The symbolism of fairy tales went deep into the old philosophical system in order to help to overcome the chaos of a dispersed mentality and show the spiritual light in the darkness of the new world of the psyche. Alchemical symbols in Victorian fairy tales regain the essence of the Ego and in consequence link the lost reader with the history of humanity and the everlasting road of spiritual evolution. Max Lüthi wrote that the heart of the fairy tale rests in simplicity; everything is painted with broad strokes. ${ }^{60}$ However, one fairy tale symbol may reflect the wisdom of the wisest. Victorians used this value of fairy tales to convey, in small alchemical pictures, the path through the darkness of the complexities of the nineteenth-century psyche.

\section{References}

Atwood M.A., Hermetic Philosophy and Alchemy: A Suggestive Inquiry into 'The Hermetic Mystery' [1918], New York 2010.

Auden W.H., Phantasy and Reality in Poetry, [in:] In Solitude, for Company: W.H Auden after 1940, K. Bucknell, N. Jenkins (eds.), Oxford 1995, pp. 139-207.

Book of Lambspring [1599], http://www.alchemywebsite.com/lambtext.html [access: 01.08.2017]. Butler S., Unconscious Memory [1880], http://www.gutenberg.org/files/6605/6605-h/6605-h.htm [access: 28.07.2017].

Carlyle T., Sartor Resartus: The Life and Opinions of Herr Teufelsdrockh: In Three Books, London 1889.

Cott J., Beyond the looking Glass: Extraordinary Works of Fantasy and Fairy Tales, Stonehill 1973.

${ }^{60}$ M. Lüthi, The Fairytale as Art Form and Portrait of Man, Bloomington 1987, p. 57. 
Crasselame M.-A., The Light Coming Out of the Darkness, http://www.alchemywebsite.com/crassel.html [access: 29.07.2017].

Eirenaeus Philalethes, An Open Entrance to the Closed Palace of the King, London 1667, http:// www.alchemywebsite.com/openentr.html [access: 27.07.2017].

Emerald Tablet, http://www.alchemywebsite.com/emerald.html [access: 27.07.2017].

Fisher K., Converse in the Spirit: William Blake, Jacob Boehme, and the Creative Spirit, Cranbury 2004.

Forman S., Of the Division of Chaos [1595], http://www.levity.com/alchemy/forman_chaos.html [access: 27.07.2017].

Foucault M., Fantasia of the Library, [in:] Language, Counter-Memory, Practice. Selected Essays and Interviews, D.F. Bouchard (ed.), New York 1977, pp. 87-113.

Franz M.-L., von, Alchemy: An Introduction to the Symbolism and the Psychology, Toronto 1980.

Hearn M.P., The Victorian Fairy Tale Book, New York 1988.

Housman L., The Gentle Cockatrice, [in:] idem, The Blue Moon, London 1904.

Housman L., The Moon-Flower, [in:] idem, A Doorway in Fairyland, New York 1900.

James W., Essays in Psychical Research, Harvard 1986.

James W., The Varieties of Religious Experience: A Study in Human Nature, London 1917.

Jung C.G., C.G. Jung Speaking: Interviews and Encounters, W. McGuire, R.F.C. Hull (eds.), Princeton 1987.

Jung C.G., Mysterium Coniunctionis: An Inquiry into the Separation and Synthesis of Psychic Opposites in Alchemy, [in:] The Collected Works of C.G. Jung. vol. 14, G. Adler (ed.), Princeton 1970.

Lüthi M., The Fairytale as Art Form and Portrait of Man, Bloomington 1987.

MacDonald G., A Dish of Orts [1867], https://www.gutenberg.org/files/9393/9393-h/9393-h.htm [access: 27.07.2017].

Maier M., A Subtle Allegory [1617], http://www.alchemywebsite.com/maier.html [access: 28.07.2017].

Maier M., Atalanta Fugiens, http://www.alchemywebsite.com/atalanta.html [access: 30.07.2017].

Morgan M. de, Seeds of Love, [in:] eadem, On a Pincushion, and Other Fairy Tales, London 1877.

Nesbit E., The Island of the Nine Whirpools, [in:] eadem, The Book of Dragons [1901], New York 1986.

Page H.A., Children and Children's Books, “The Contemporary Review” 1869, vol. XI, MayAugust.

Principe L.R., Newman W.R., Alchemy Tried in Fire: Starkey, Boyle, and the Fate of Helmontian Chymistry, Chicago-London 2002.

The Parabola of Madathanus, http://www.alchemywebsite.com/parabola.html [access: 28.07.2017].

The Rosary of the Philosophers [1550], http://www.alchemywebsite.com/rosary2.html [access: 27.07.2017].

Underhill E., The Miracles of Our Lady Saint Mary [1905], New York 2015.

Waite A.E., Azoth, Or, The Star in the East, London 1893.

Zipes J., Victorian Fairy Tales: The Revolt of the Fairies and Elves, New York 1987. 